mgr inż. Jacek Krawczyk

Instytut Pojazdów Szynowych ,TABOR”

\title{
Zmodernizowane kabiny sterownicze lokomotyw elektrycznych i spalinowych
}

\begin{abstract}
$W$ artykule dokonano przegladu kabin sterowniczych wybranych lokomotyw i stanowisk sterowniczych przed modernizacja, pokazano przebieg prac przy modernizacji kabin lokomotyw z wykorzystaniem modeli 3D kabin lokomotyw przed modernizacja, a po modernizacji pokazano modele $3 D$ zmodernizowanych kabin i nowych stanowisk sterowniczych (konsola, dolna część pulpitu) razem z fotelami oraz zaprezentowano widoki lokomotyw po modernizacji wraz z kabinami i stanowiskami sterowniczymi po modernizacji. Praca dotyczaca modernizacji kabin zostata wykonana $w$ ramach projektu rozwojowego NR 10-0062-10/2011 pt. „Lokomotywy manewrowe z hybrydowym uktadem napędowym z wykorzystaniem wysokowydajnych zasobników energii" i sfinansowana przez NCBR.
\end{abstract}

\section{WSTĘP}

Obecne eksploatowane na liniach kolejowych pojazdy szynowe takie, jak lokomotywy liniowe, lokomotywy manewrowe, zespoły trakcyjne, autobusy szynowe znajdują się w różnym stanie technicznym. Po wielu latach niedoinwestowania polskich kolei tabor, a szczególnie lokomotyw spalinowe, wymaga modernizacji.

Średni wiek lokomotyw największych przewoźników na rynku pasażerskim, PKP Intercity oraz Przewozów Regionalnych, aktualnie przekracza 26 lat. Na rynku przewozów towarowych na ogólną liczbę eksploatowanych $\sim 3500$ lokomotyw, $\sim 1600$ miało więcej niż 30 lat, a $\sim 1700$ miało $26 \div 30$ lat, natomiast tylko $\sim 150$ było $\mathrm{w}$ wieku $16 \div 25$ lat, zaś kilkanaście lokomotyw (będących w posiadaniu PKP CARGO) nie przekroczyło 15 lat. Lokomotywy będące w posiadaniu prywatnych przewoźników (ponad 400 sztuk) to lokomotywy, których wiek przekracza 40 lat.

Ze względów ekonomicznych nie jest możliwa w krótkim czasie wymiana całego taboru, na nowy spełniający aktualne wymagania i przepisy (UIC-651, UIC-612), oraz odpowiednich norm PN-EN. Wiele tych pojazdów ma ograniczone możliwości eksploatacyjne, ze względu na stan techniczny i warunki pracy obsługi oraz wymagania środowiskowe. Z kolei nowe pojazdy są zbyt drogie, pozostaje zatem modernizacja.

Drugą przesłanką opłacalności modernizacji lokomotyw liniowych jest to, że na ogół ostoja i szkielety pudła są w dobrym stanie, nie są skorodowane i mają wystarczającą wytrzymałość. Wynika to między innymi przyjętymi w czasach ich budowy wysokimi współczynnikami bezpieczeństwa.

Jednym z ważniejszych elementów lokomotyw jest kabina sterownicza. W starych kabinach lokomotyw warunki pracy maszynisty nie spełniają już współczesnych wymagań, odnośnie ergonomii, komfortu klimatycznego i akustycznego oraz wyposażenia, dlatego przy okazji modernizacji lokomotyw zachodzi konieczność gruntownej modernizacji kabin sterowniczych, stanowiska sterowniczego, podłogi, wyłożenia kabiny, oświetlenia, izolacji termicznej i akustycznej. Ponadto kabina powinna być wyposażona w urządzenia socjalne jak szafki, kuchenki, umywalkę oraz lodówkę.

Całe wnętrze kabiny powinno spełniać warunki wg UIC-651 [5] oraz wymagania odpowiednich norm PN-EN, zaś stanowisko sterownicze wymagania UIC-612 [4] oraz wyposażone być wyposażone $\mathrm{w}$ ergonomiczne fotele $\mathrm{z}$ możliwością regulacji.

\section{KABINY STEROWNICZE LOKOMOTYW PRZED MODERNIZACJĄ}

\subsection{Lokomotywa spalinowa 301Db (SP45 i SU45)}

Lokomotywy te powstały w latach 1970-1976 w Zakładach Metalowych im. H. Cegielskiego w Poznaniu. Były one przeznaczone do ruchu towarowego oraz pasażerskiego (SP45) na niezelektryfikowanych liniach kolejowych. Ogółem wyprodukowano 270 lokomotyw tego typu. SP45 jest lokomotywą sześcioosiową o układzie osi Co-Co (dwa wózki trzyosiowe). Po modernizacji polegającej na ujednoliceniu systemu (ogrzewanie elektryczne zamiast parowego), zmodernizowane pojazdy oznaczono serią SU45.

Pudło lokomotywy stanowi spawana ostoja i ściany boczne, które wraz z dachem stanowią konstrukcję samonośną. Na obu końcach ostoi umieszczono szkielety kabiny maszynisty, które są przyspawane do ścian bocznych i ostoi. 

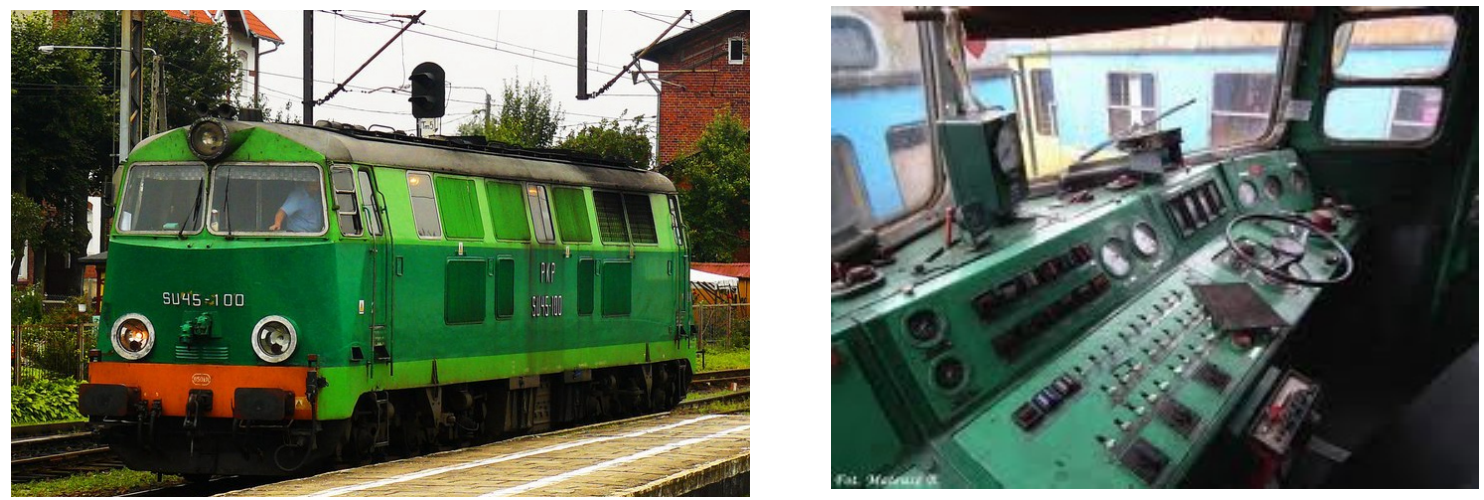

Rys. 1. Widoki ogólne lokomotywy i kabiny oraz stanowiska sterowniczego 301Db (SU45) przed modernizacją

\subsection{Lokomotywa spalinowa 303D (SU46)}

Projekt tej lokomotywy powstał w 1972 roku jako rozwinięcie konstrukcji lokomotywy 301Db (serii SP45). Lokomotywy powstały w latach $1974 \div 1977$. Wyprodukowano 52 sztuk lokomotyw a w roku 1985 wykonano jeszcze dwa zmodyfikowane egzemplarze. Były one przeznaczone do ruchu pasażerskiego i towarowego na niezelektryfikowanych liniach kolejowych.
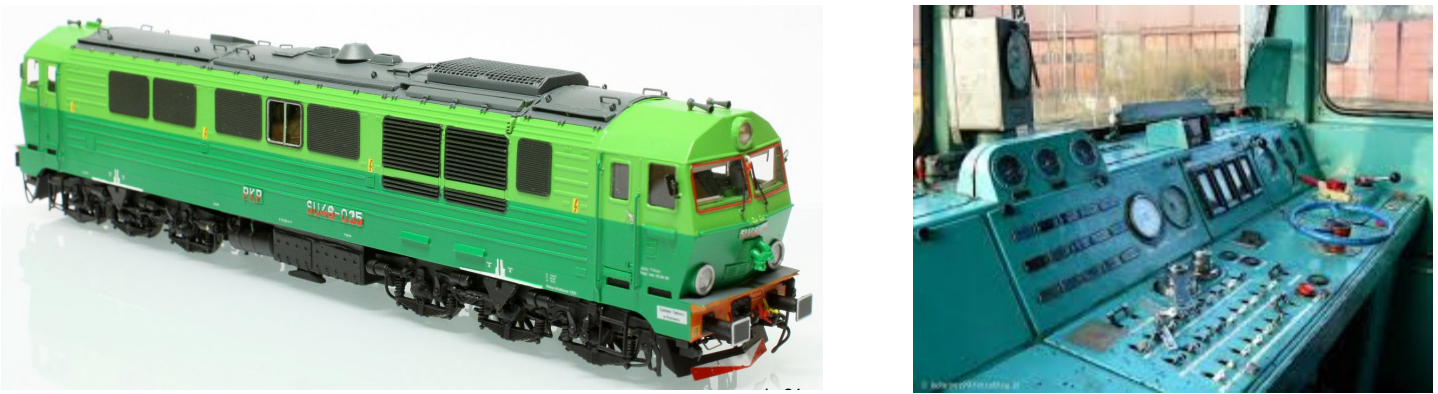

Rys. 2. Widok lokomotywy i kabiny 303D (SU46) przed modernizacją

\subsection{Lokomotywa elektryczna 201E (ET22)}

Założenia konstrukcyjne opracowano w latach 1965-1966, a prototypy wyprodukowane zostały w Pafawagu Wrocław w 1969. W roku 1972 ruszyła produkcja seryjna. Sa to lokomotywy przeznaczone do ciężkich przewozów towarowych. Dla PKP wyprodukowano ogółem 1183 sztuk.
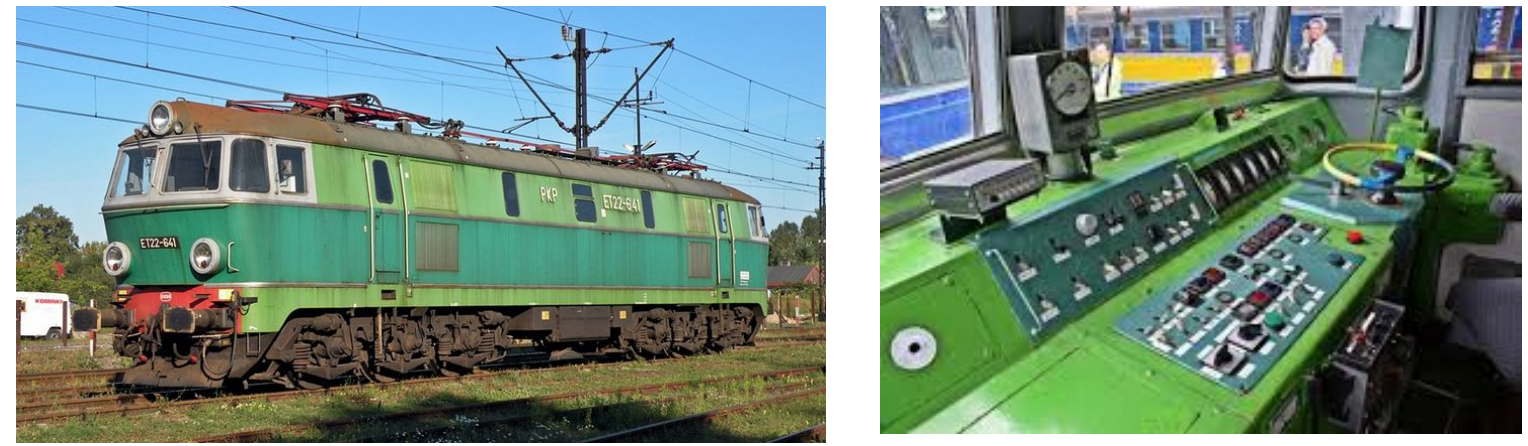

Rys. 3. Widok lokomotywy i kabiny 201E (ET22) przed modernizacją

\subsection{Lokomotywa elektryczna (4E) EU-07}

Produkcję tych lokomotyw rozpoczęto od 1965 w Pafawagu we Wrocławiu i do roku 1974 zbudowano 240 sztuk EU-07 (typ 4E). W 1983 produkcję wznowiono w zakładach „H. Cegielskiego” w Poznaniu jako seria EU-07 (typ 303E).

W nowej EU07 pojawiło się wiele modyfikacji i nadano jej oznaczenie fabryczne 303E. Lokomotyw tego typu wykonano łącznie 243 (numery 301-543). Produkcję seryjną kontynuowano aż do roku 1992.

Te uniwersalne lokomotywy przeznaczone są do prowadzenia pociagów pośpiesznych o masie do $700 \mathrm{t} \mathrm{z}$ prędkością maksymalną do $125 \mathrm{~km} / \mathrm{h}$ albo lekkich pociągów towarowych o masie do $2000 \mathrm{t}$ z prędkością maksymalną $70 \mathrm{~km} / \mathrm{h}$.

W modelu 303E zastąpiono dotychczasowe pudła samonośne pudłami z ostojnicą i bocznymi ścianami ryflowanymi, zamontowano również większe zgarniacze pod czołownicą. 

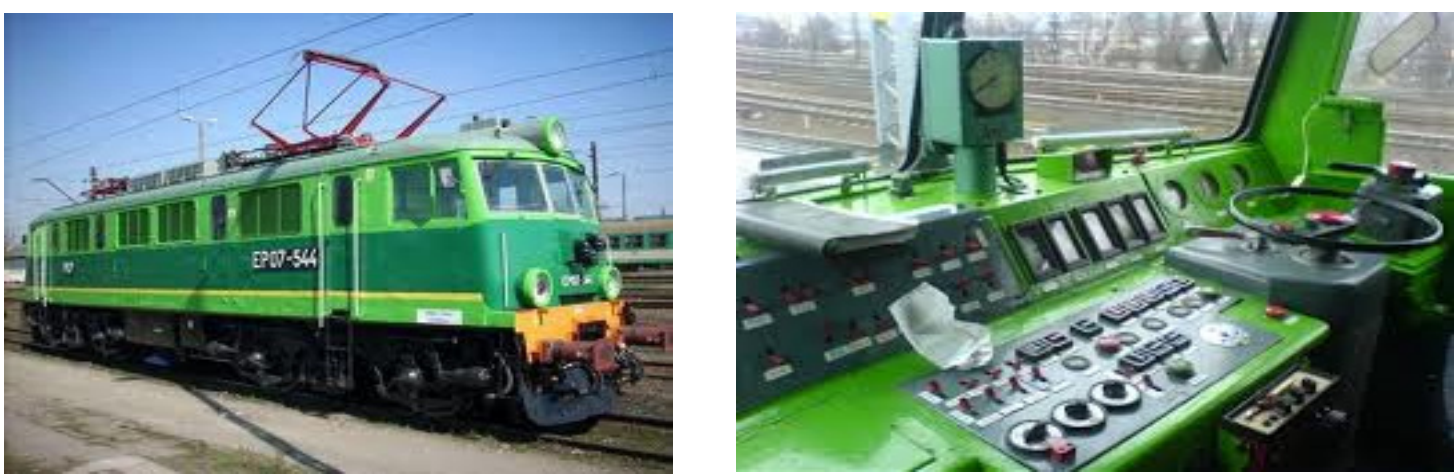

Rys. 4. Widok lokomotywy i kabiny 4E (EU-07) przed modernizacją

\subsection{Lokomotywa spalinowa SP32}

Lokomotywy SP32 powstały w 1985 roku na zamówienie PKP i były produkowane w Rumunii. Zostały one przeznaczone do obsługi lekkiego ruchu pasażerskiego. Wyprodukowano łącznie dla PKP 150 sztuk tych lokomotyw. Lokomotywę tą pokazano wraz ze stanowiskiem sterowniczym na rys. 5.
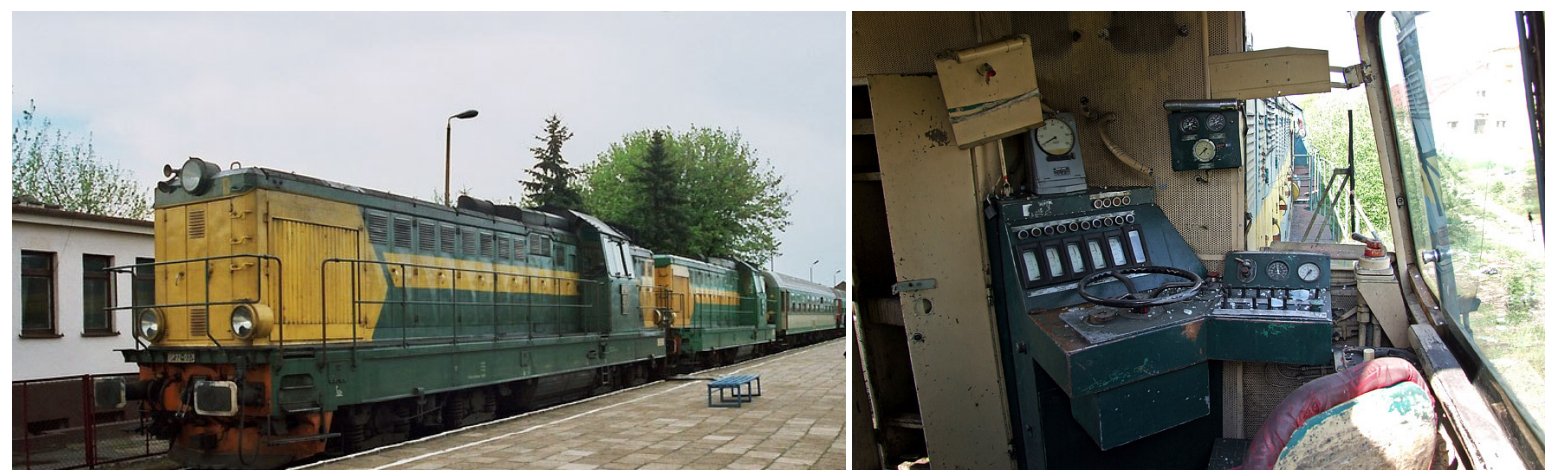

Rys. 5 Widok lokomotywy i kabiny SP32 przed modernizacją

\subsection{Lokomotywa spalinowa manewrowa 6D (SM42)}

Jest to podstawowa manewrowa lokomotywa spalinowa przeznaczona do ciężkich prac manewrowych oraz prowadzenia pociagów. Została zaprojektowana na przełomie lat 50 i 60 -tych. Produkcja tej lokomotywy była prowadzona do roku 1981 i została wznowiona w niewielkim zakresie w 1985 roku. Łącznie wyprodukowano ponad 660 sztuk tych lokomotyw.

Lokomotywy te są eksploatowane zarówno na torach PKP, torach leżących na terenach zakładów produkcyjnych jak oraz stacjach rozrządowych.

Widoki tej lokomotywy i wnętrza kabiny ze stanowiskiem sterowniczym przed modernizacją przedstawiono na rysunku 6.
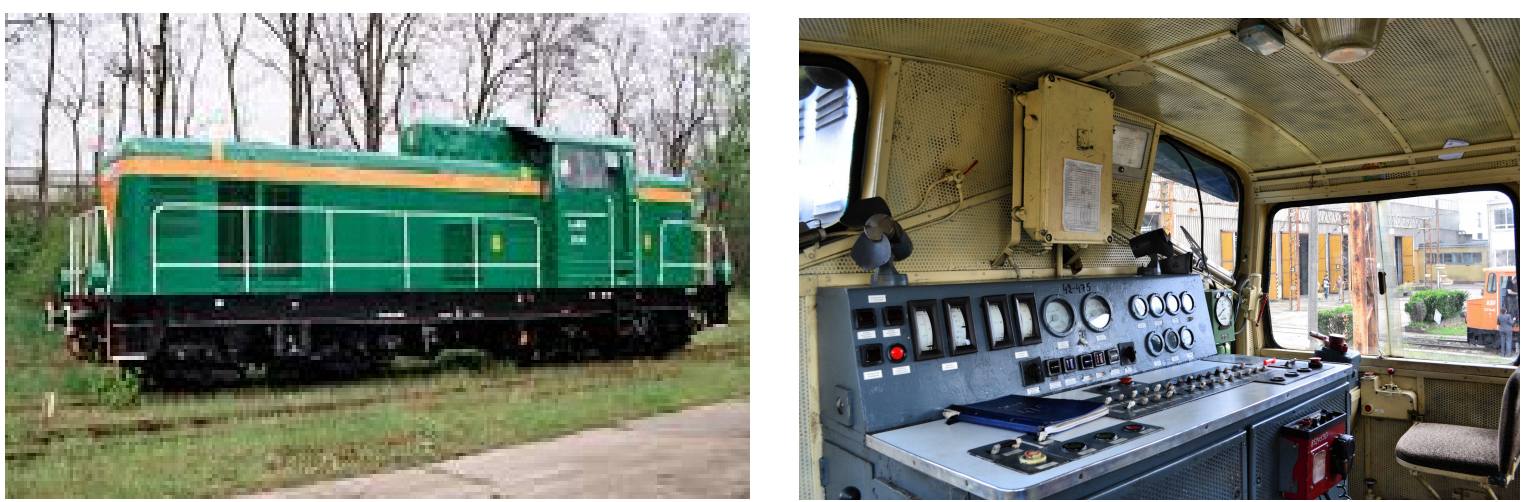

Rys. 6. Widok lokomotywy i kabiny SM42 (6D) przed modernizacją

\section{MODELE 3D LOKOMOTYW PRZED MODERNIZACJĄ}

Z uwagi na charakter pracy przy pracach projektowo-koncepcyjnych i obliczeniach (praca narzędziami w systemach 3D), dostępne dane wyjściowe pudła lokomotyw przed modernizacją w postaci dokumentacji płaskiej (papierowej), są niewystarczające. 
Dlatego przed przystapieniem do dalszych prac, konieczna jest konwersja danych rysunkowych pudła lokomotyw do modelu 3D (ostoi i ścian bocznych oraz kabin), jako najbardziej przydatnego do dalszych prac projektowych [8].

Na podstawie dostępnej dokumentacji technicznej (w postaci papierowej) dokonano konwersji wybranych fragmentów konstrukcji lokomotywy, szkieletu pudła z poszyciem, ostoi i obu szkieletów kabiny z poszyciem na końcu pudła w skali 1:1.

W modelach tych pominięto stare wyłożenia, pulpity, różne instalacje (pneumatyczne, wodne i elektryczne), części przyspawane, gdyż w modernizowanych lokomotywach będą one robiono na nowo. Modele 3D poszczególnych lokomotyw przed modernizacją przedstawiono na rys $7 \div 11$ [9].
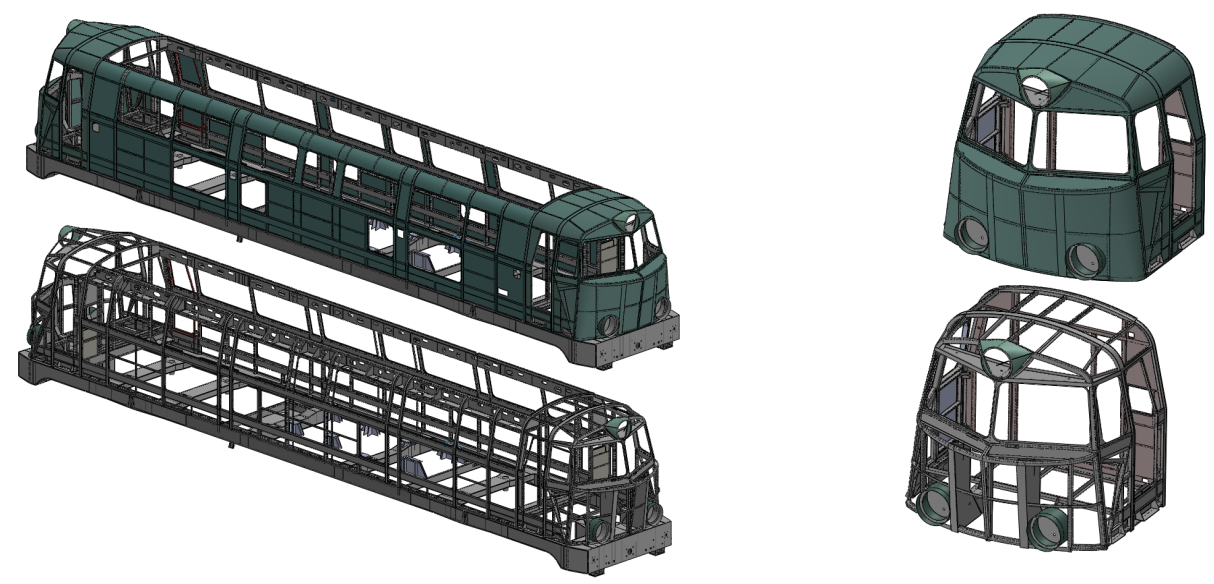

Rys. 7. Widok na model szkieletu pudła i kabiny (z poszyciem oraz bez) lokomotywy 301Dd (SU45) przed modernizacją
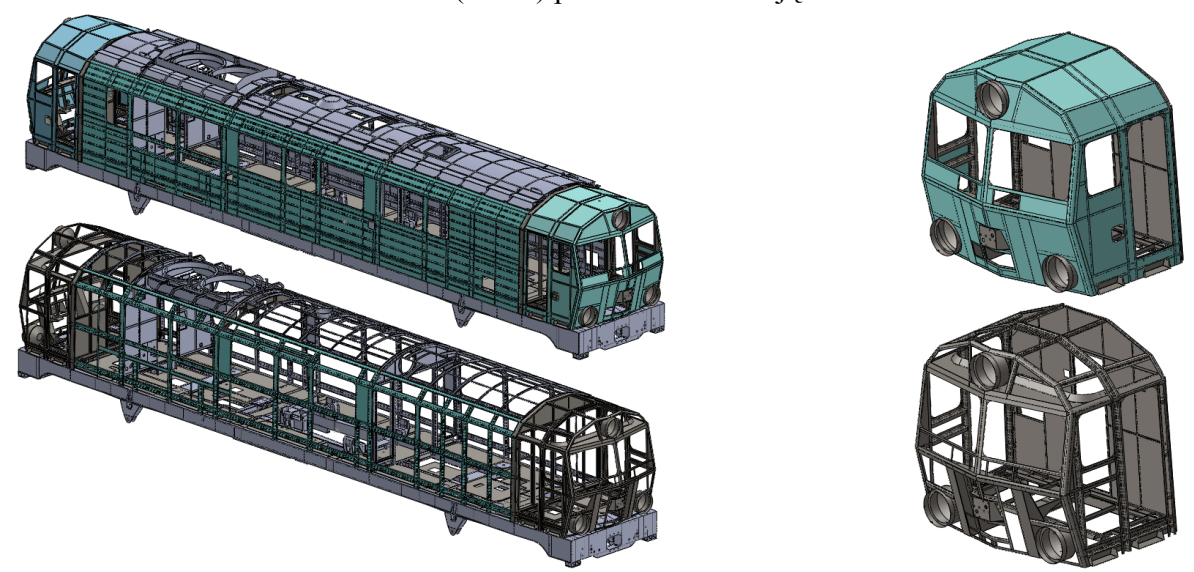

Rys. 8. Widok na model szkieletu pudła i kabiny (z poszyciem oraz bez) lokomotywy 303D (ST46) przed modernizacją
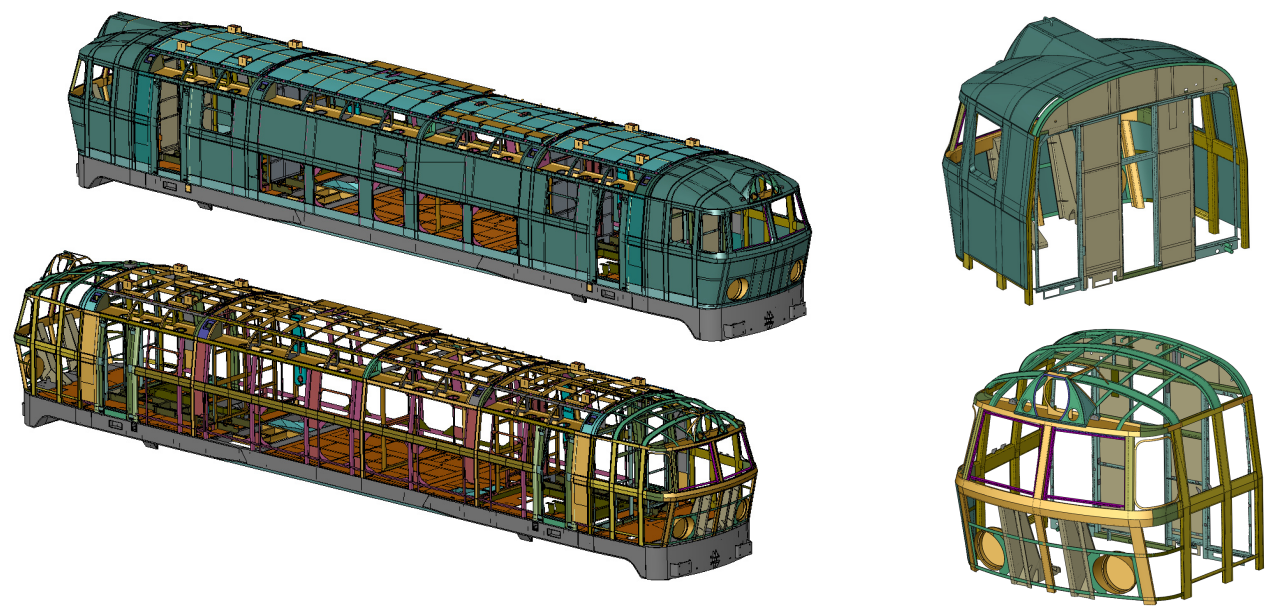

Rys. 9. Widok na model szkieletu pudła i kabiny (z poszyciem oraz bez) lokomotywy 201E (ET22) przed modernizacją 

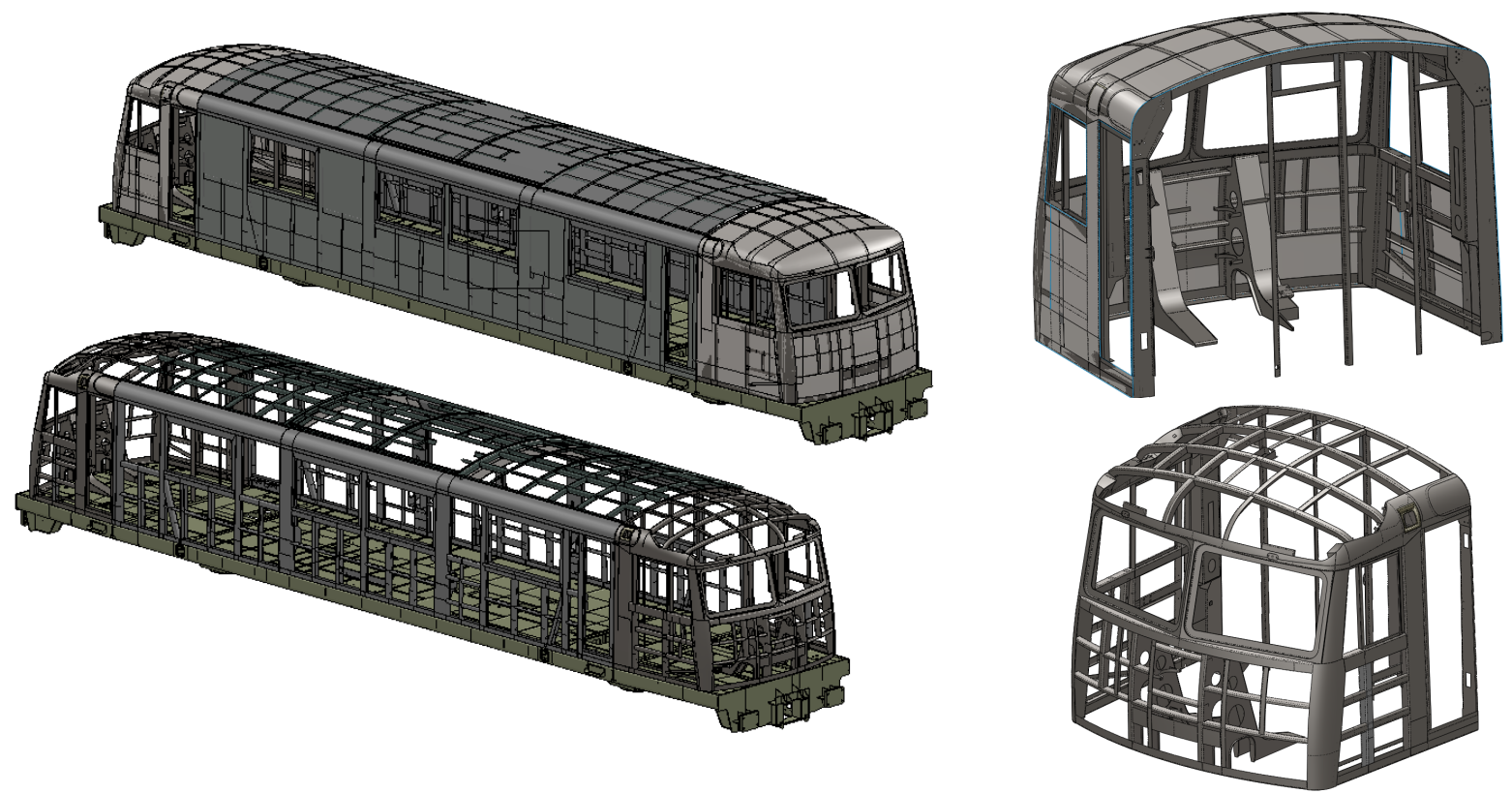

Rys. 10. Widok na model szkieletu pudła i kabiny (z poszyciem oraz bez) lokomotywy EU-07 (303E) przed modernizacją

$\mathrm{Na}$ podstawie dostępnej dokumentacji papierowej lokomotywy SP-32 wykonano model 3D szkieletu kabiny przedstawiony $\mathrm{w}$ widoku aksonometrycznym i eksplodowanym na rys. 11.
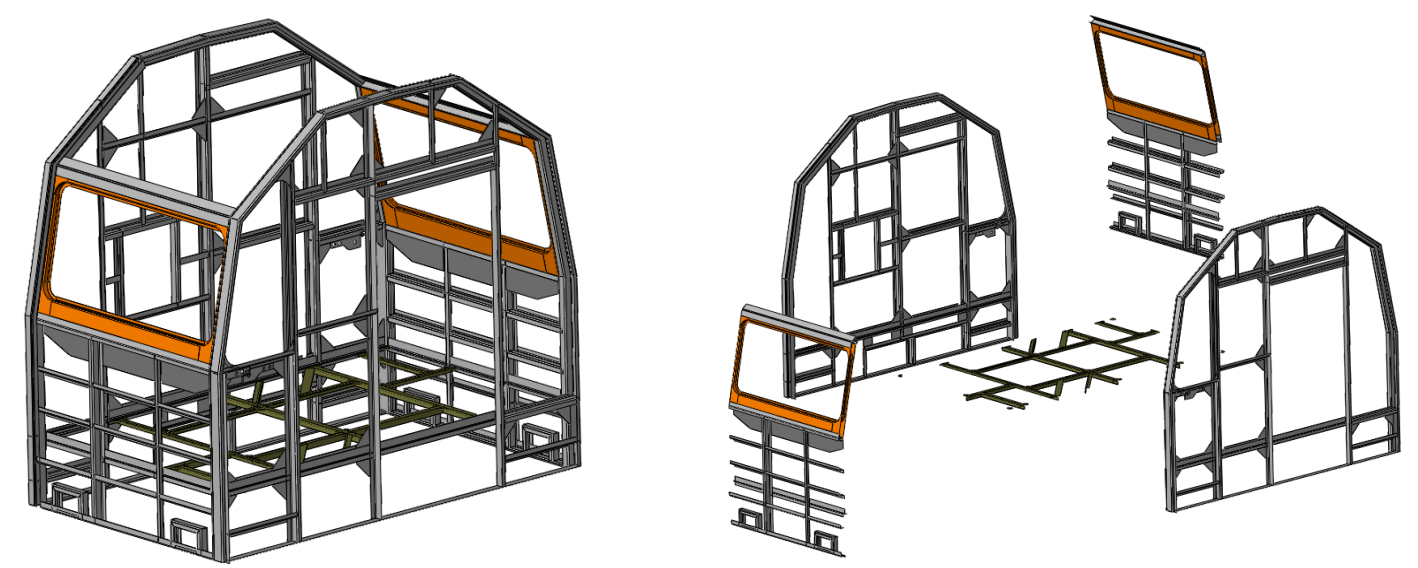

Rys. 11. Widok na model szkieletu i widok rozłożony szkieletu kabiny lokomotywy SP32 przed modernizacją

Modernizacja lokomotywy manewrowej SM42 (rys. 6) ma polegać na modernizacji w ograniczonym zakresie wózków i ostoi. Całe stare nadwozie tj. kabina maszynisty i przedziały maszynowe będą całkowicie usunięte, a $\mathrm{w}$ ich miejsce zostanie zabudowane całkowicie nowe nadwozie wraz nową kabina, dlatego wykonano konwersję do modelu 3D tylko ostoi lokomotywy. Model przedstawiono na rys. 12 .

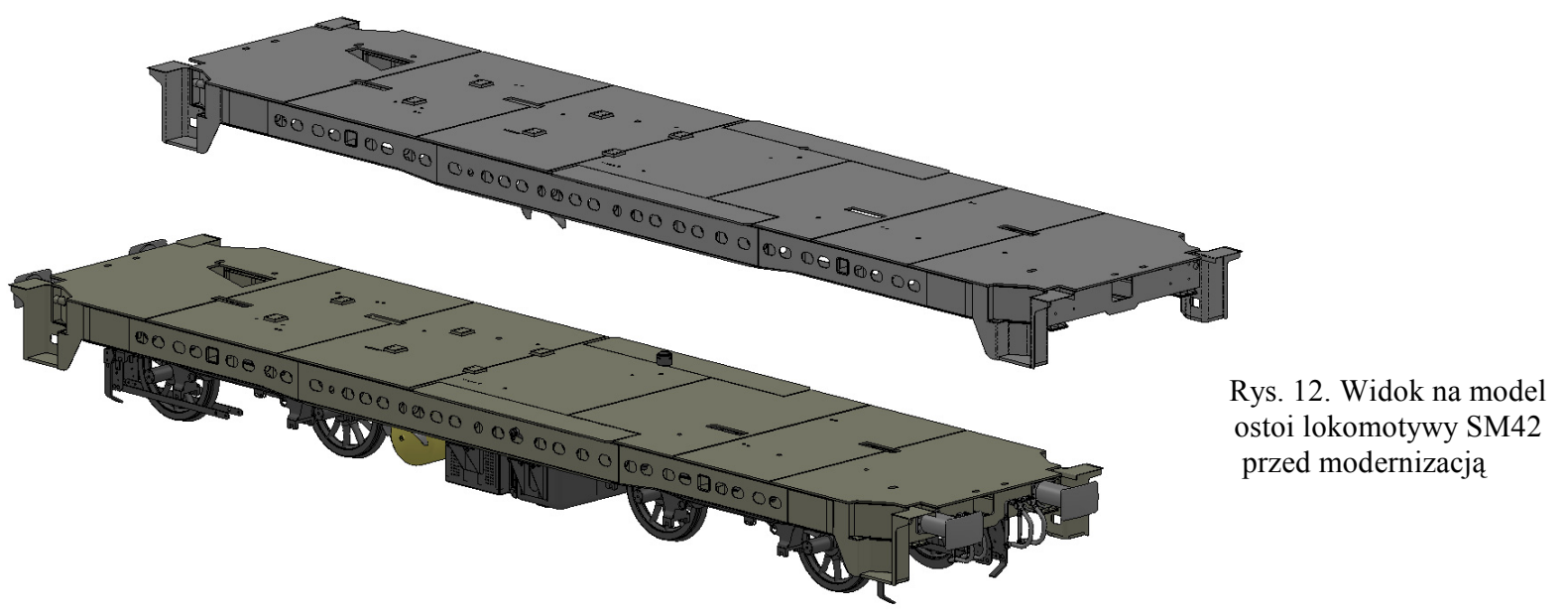




\section{WYMAGANIA PROJEKTOWE STANOWISKA STEROWNICZEGO W MODERNIZO- WANEJ KABINIE}

$\mathrm{Na}$ tak przygotowanych modelach 3D kabiny maszynisty wykonano analizy przestrzenne związane z kształtowaniem geometrii wyjściowej pulpitu górnego (konsoli) i dolnego wraz z rozmieszczeniem na konsoli urządzeń wskaźnikowych i sterujących zgodnie $\mathrm{z}$ aktualnymi wymaganiami i zasadami ergonomii oraz z zabudową aparatów pulpitowych w dolnej części pulpitu[2].

Ze względu na dużą złożoność geometrii stanowiska sterowniczego, a przez to złożone analizy przestrzenne, wykorzystano utworzone na bazie dokumentów UIC [5] i norm niektóre pomocnicze szablony z wymaganymi wymiarami, które następnie wykorzystano w tych analizach. Szablony przedstawiono poniżej.

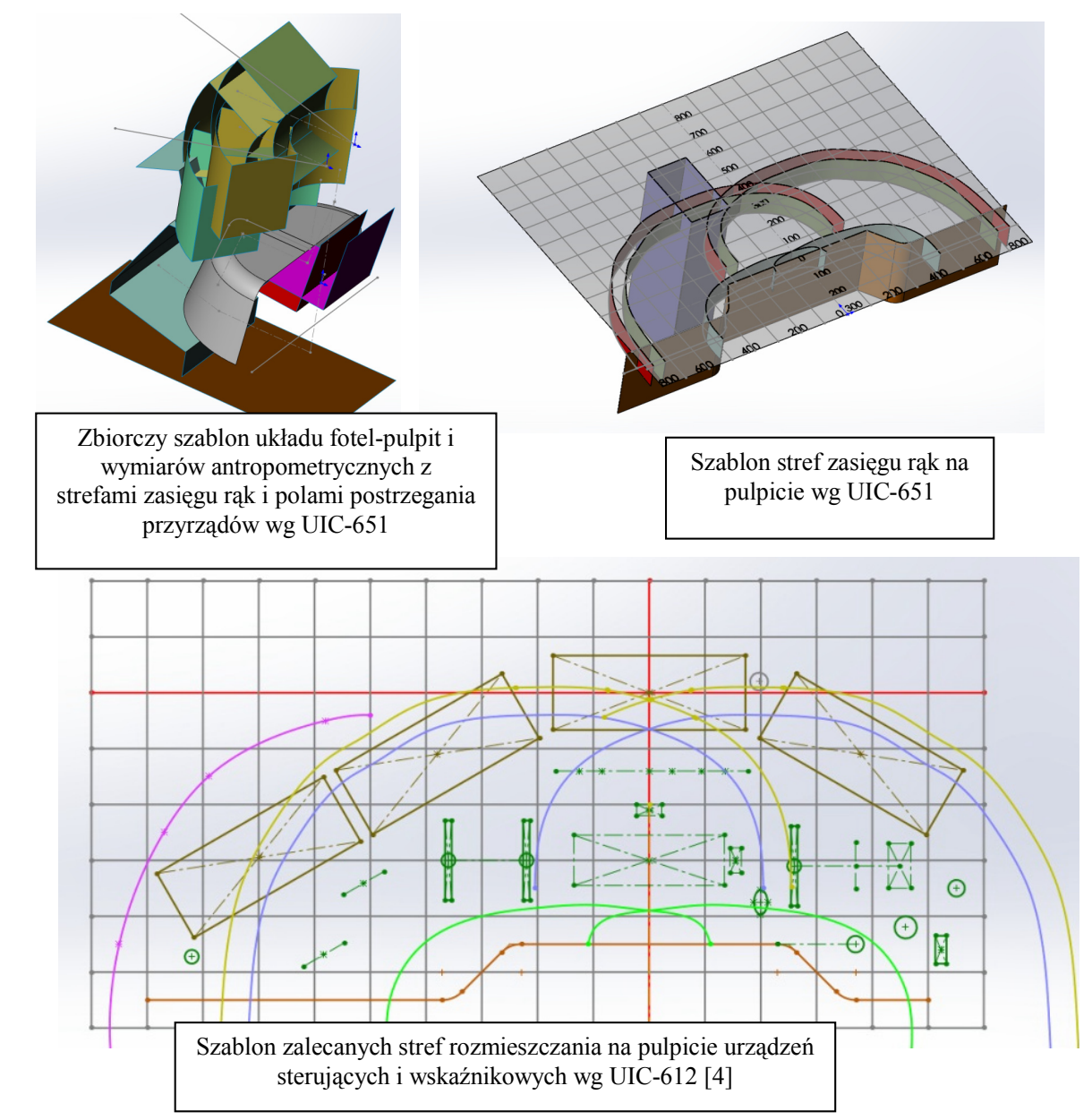

Rys.13. Szablony wykorzystane do analiz i tworzenia geometrii stanowiska sterowniczego

Takie podejście do projektowania umożliwiło analizę jednocześnie bardzo wielu złożonych informacji w różnych aspektach, w rozsądnym czasie i usprawniło proces kształtowania konstrukcji pulpitu oraz zabudowy urządzeń pulpitowych. Możliwe stało się również wykrywanie i eliminowanie kolizji między elementami składowymi pulpitu na etapie koncepcji, bez konieczności budowy prototypu pulpitu celem weryfikacji.

Struktura stanowiska sterowniczego była kształtowana wraz z zabudową różnorodnych urządzeń sterujących, aparatów elektrycznych, urządzeń wskaźnikowych i pomocniczych, zarówno na pulpicie jak i pod pulpitem[1].

Tak ukształtowaną geometrię wyjściową stanowiska sterowniczego w kabinie sprawdzono pod względem widoczności sygnałów wysokich i niskich wg wymagań UIC-651 pokazanych na rys. 14.

$\mathrm{Na}$ tak przygotowanych modelach 3D wykonano prace koncepcyjno-konstrukcyjne związane $\mathrm{z}$ tworzeniem stanowisk sterowniczych, pulpitu dolnego i górnego, oraz modyfikowano kabinę wraz z zabudową urządzeń i kształtowaniem struktury kabiny (okna czołowe i boczne, podłoga, drzwi wejściowe, wyłożenia wraz z izolacją i wygłuszaniem). 


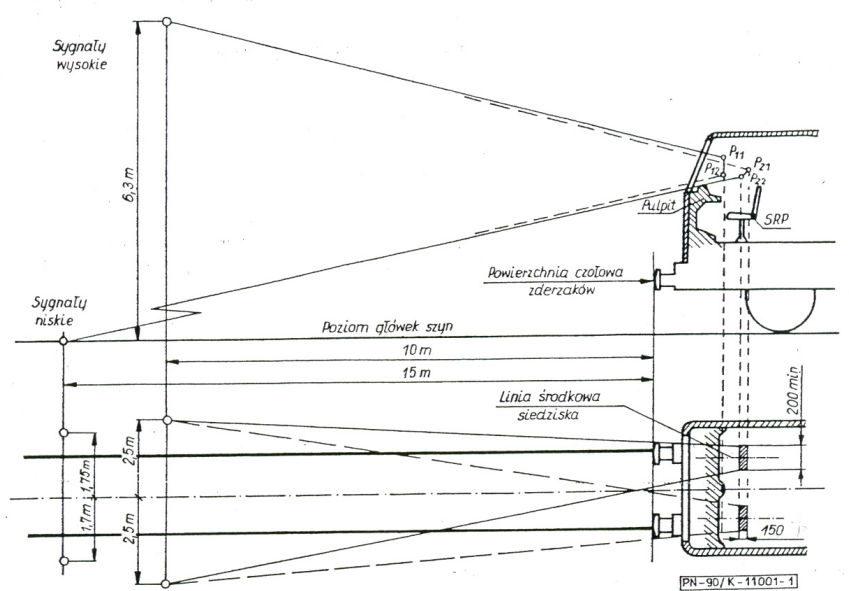

Rys. 14. Widoczność szlaku wg karty UIC 651 [5]

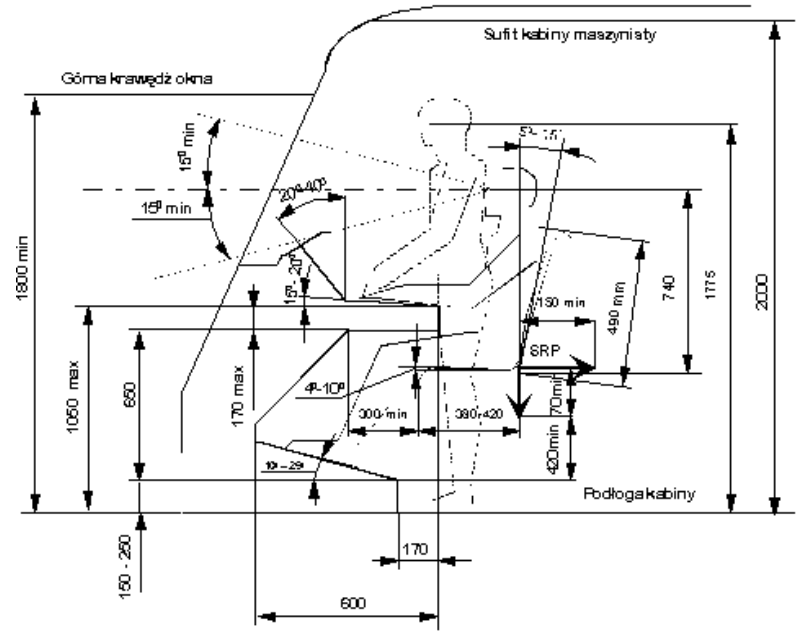

Rys. 15. Zalecane wg UIC-651 główne wymiary układu pulpit-fotel.

Tak ukształtowane geometrie wyjściowe stanowiska sterowniczego w postaci modelu 3D zostały poddane trójwymiarowej analizie i weryfikacji.

W układzie pulpit-fotel maszynisty sprawdzono czy:

- zapewnione jest łatwe siadanie i wstawanie

- zagwarantowana jest dostateczna swoboda ruchu kolan i ud w przypadku obrotu fotela

- zapewniona jest dobra praca maszynisty w pozycji siedzącej i stojącej

- łatwa jest okresowa zmiana pozycji siedzącej na stojącą.

Sprawdzono czy główne wymiary układu pulpit-fotel maszynisty są zgodne z wymaganiami UIC-651 (rys. 15), oraz sprawdzono czy rozmieszczone na pulpicie urządzenia sterujące, załączające i wyłączające, leżą w strefach optymalnego zasięgu rąk oraz czy urządzenia wskaźnikowe (panel wyświetlacza i lampki kontrole) są dobrze widoczne w każdych warunkach oświetlenia.

\section{MODELE 3D ZMODERNIZOWANYCH KABIN LOKOMOTYW I NOWYCH STANO- WISK STEROWNICZYCH}

Wszystkie te prace były wykonane na wyjściowym modelu 3D kabiny. W efekcie tych prac powstały wersje wirtualne w postaci modelu $3 \mathrm{D}$, zawierające praktycznie wszystkie informacje jakie mają rzeczywiste prototypy fizyczne zmodernizowanych kabin lokomotyw wraz ze stanowiskami sterowniczymi i wyposażeniem kabiny.

Struktura tego modelu w pełni odpowiada strukturze dokumentacji rysunkowej, która powstała na podstawie tych modeli. Widoki modeli kabin i stanowisk sterowniczych zaprezentowano na rys. $16 \div$ 21.
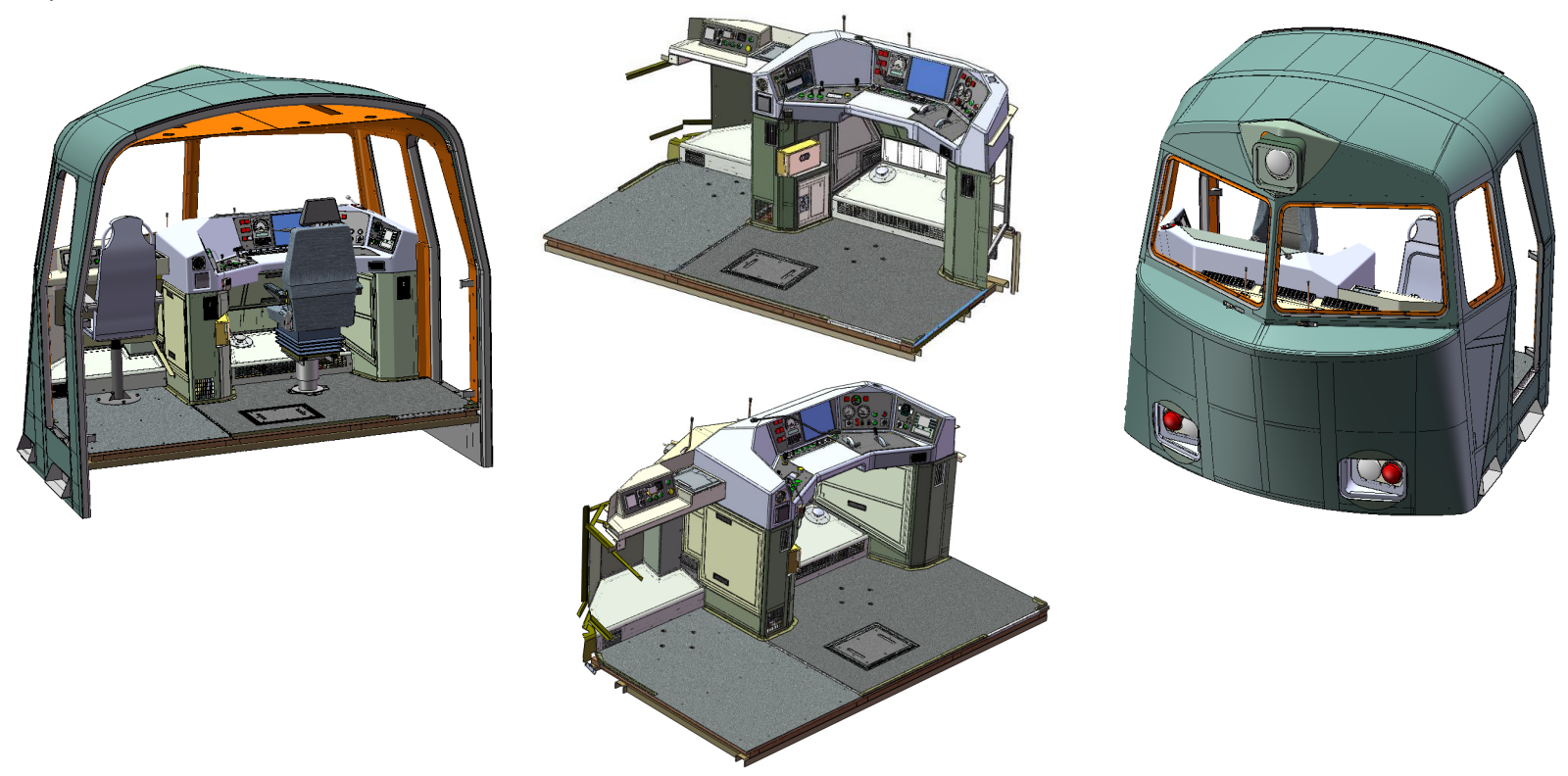

Rys. 16. Model modernizowanej kabiny z stanowiskiem sterowniczym lokomotywy 301Dd (ST45) 

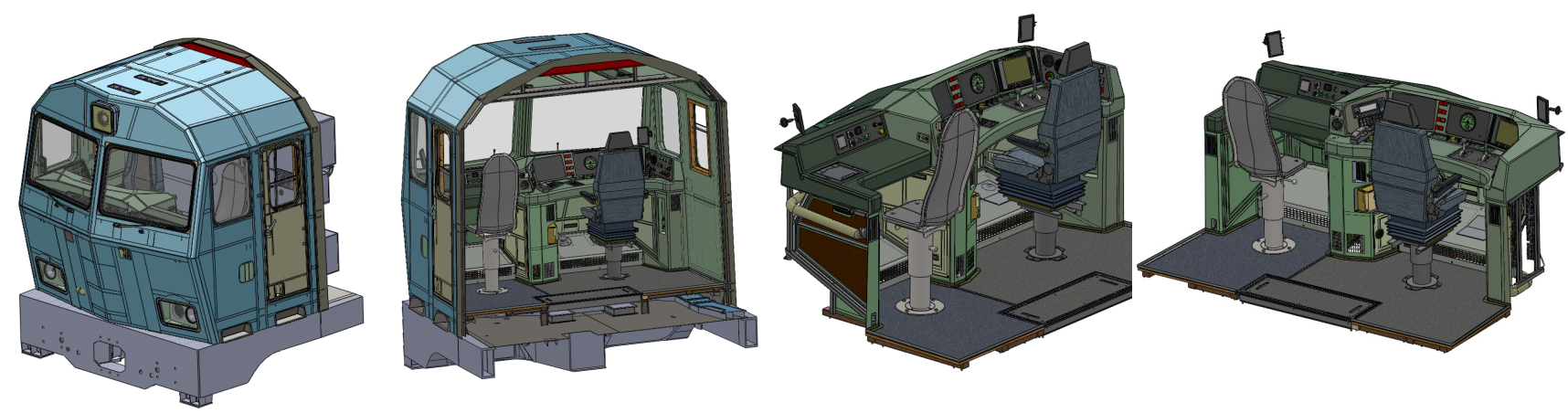

Rys. 17. Model modernizowanej kabiny z stanowiskiem sterowniczym lokomotywy 303D (ST46) [6], [7]
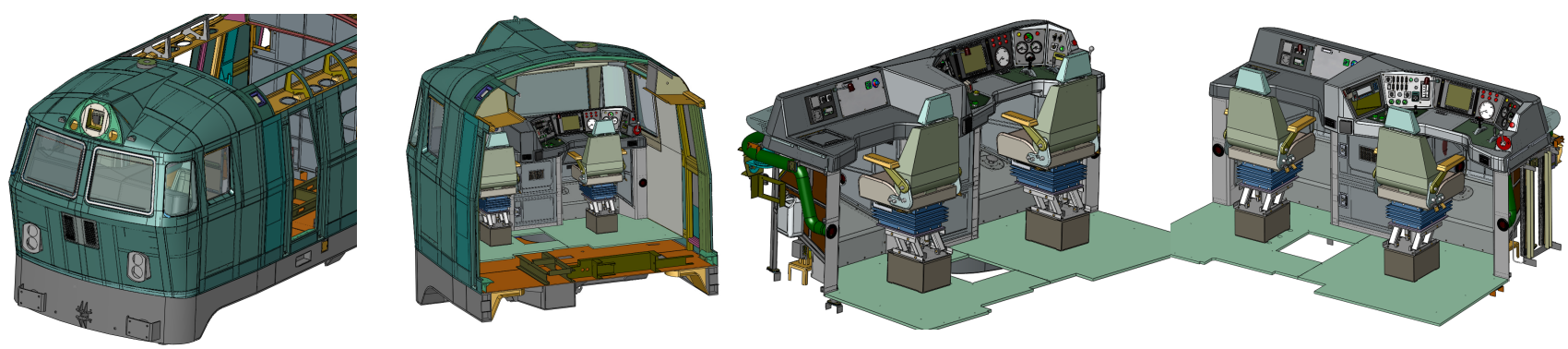

Rys. 18. Model modernizowanej kabiny z stanowiskiem sterowniczym lokomotywy 201Em (ET 22)
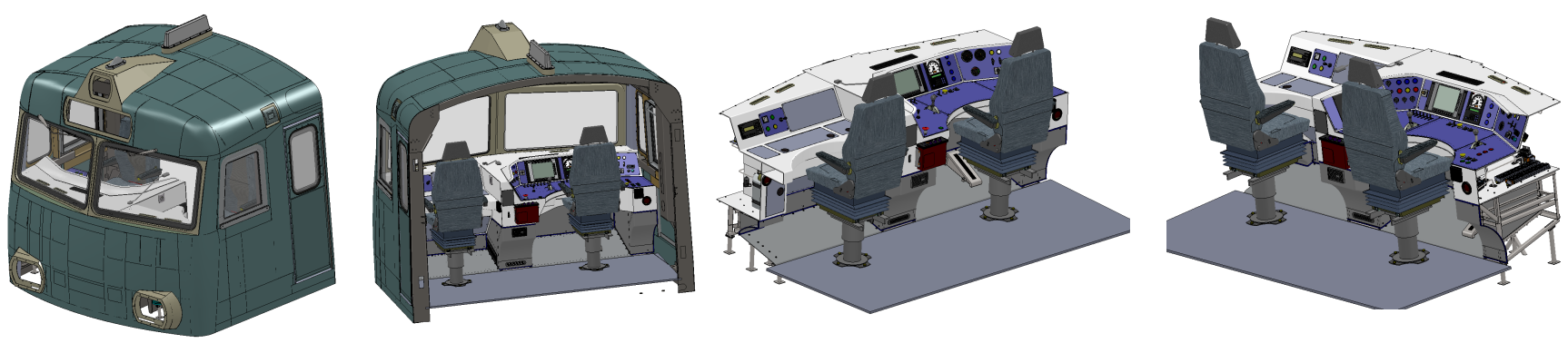

Rys. 19. Model modernizowanej kabiny z stanowiskiem sterowniczym lokomotywy 303E (EU-07)
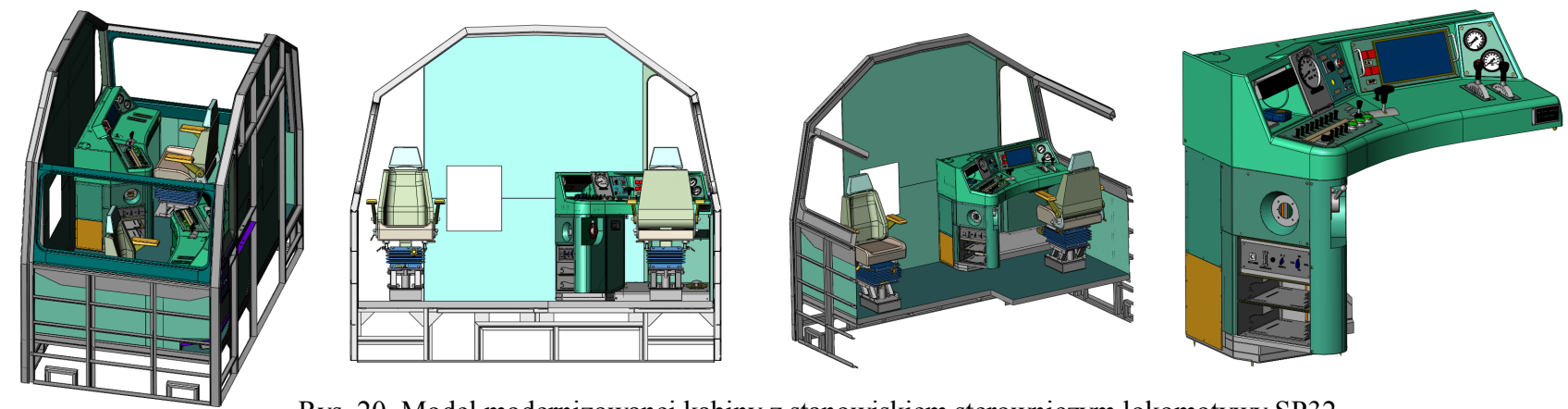

Rys. 20. Model modernizowanej kabiny z stanowiskiem sterowniczym lokomotywy SP32
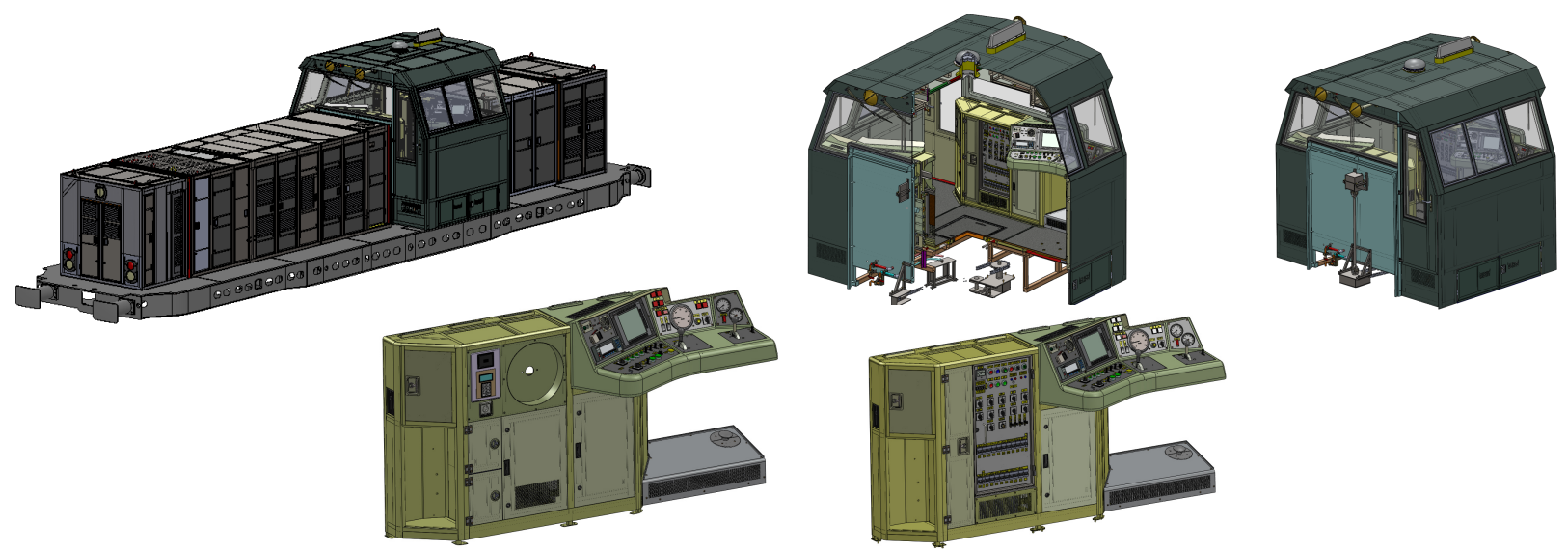

Rys. 21. Model lokomotywy i kabiny 6Di oraz stanowiska sterownicze po modernizacji 
Lokomotywa SM42 po modernizacji jako typ 6Di przedstawiona jest w postaci tylko modelu gdyż aktualnie trwają prace przy budowie prototypu.

Na podstawie ww. przedstawionych modeli została wykonana kompletna dokumentacja techniczna dla modernizacji lokomotyw.

\section{PREZENTACJA ZMODERNIZOWANYCH LOKOMOTYW}

Poniżej na rys. $22 \div 27$ zaprezentowano zdjęcia lokomotyw, kabin sterowniczych wybranych lokomotyw wraz z nowymi stanowiskami sterowniczymi.
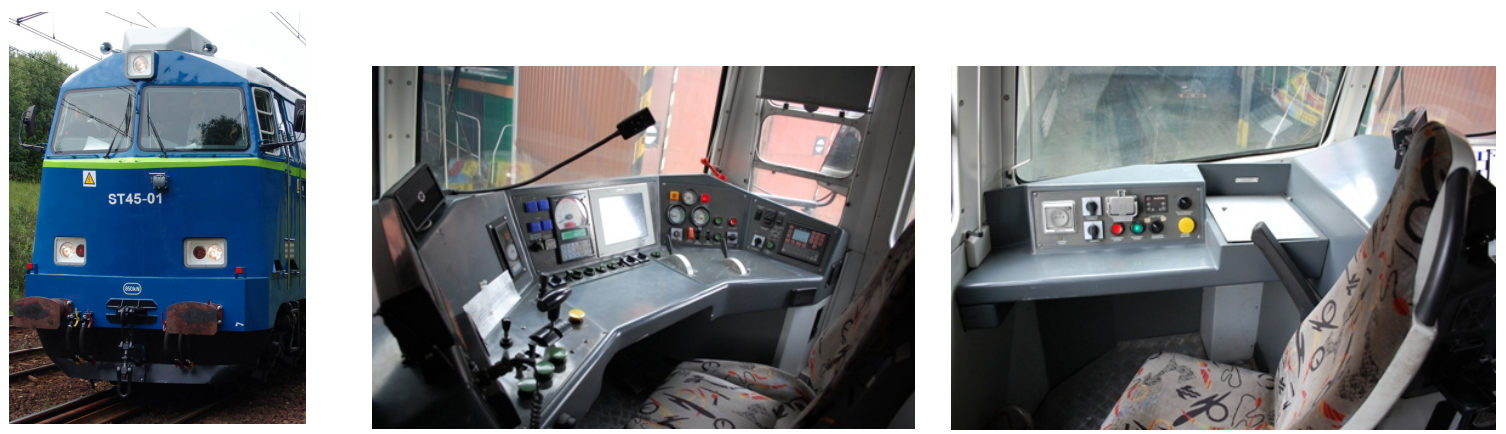

Rys. 22. Widok lokomotywy 301Dd (ST45) oraz kabiny po modernizacji z nowymi stanowiskami sterowniczymi
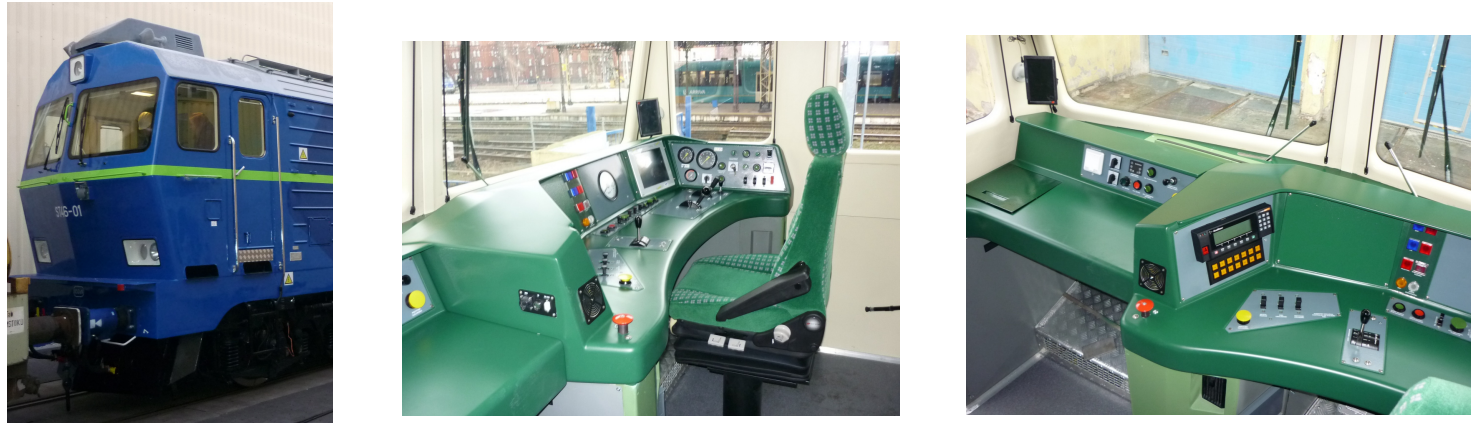

Rys. 23. Widok lokomotywy 303D (ST46) oraz kabiny po modernizacji z nowymi stanowiskami sterowniczymi
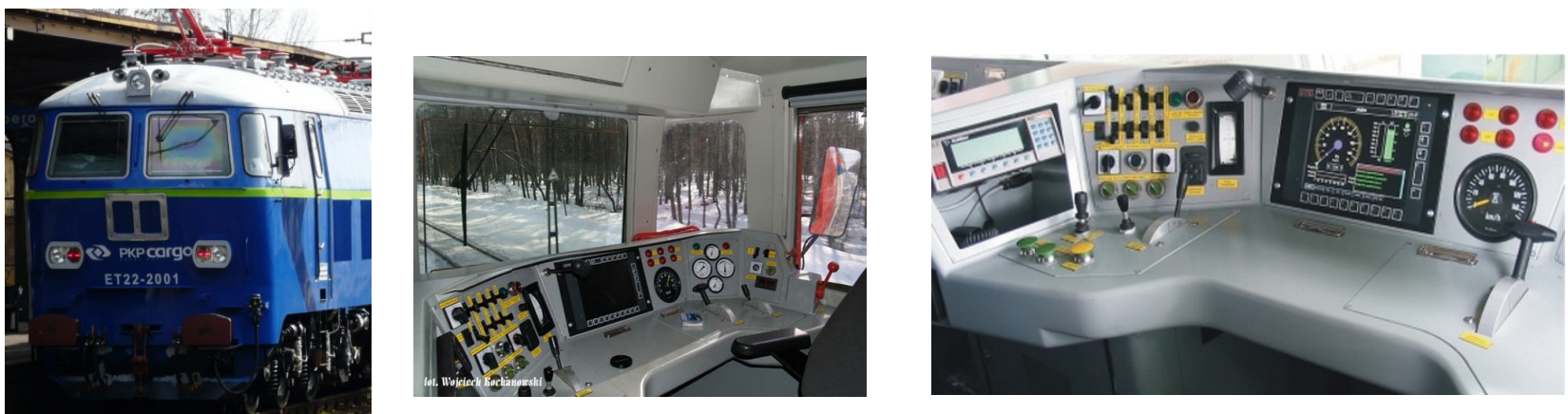

Rys. 24. Widok lokomotywy 201Em (ET22) oraz kabiny po modernizacji z nowymi stanowiskami sterowniczymi
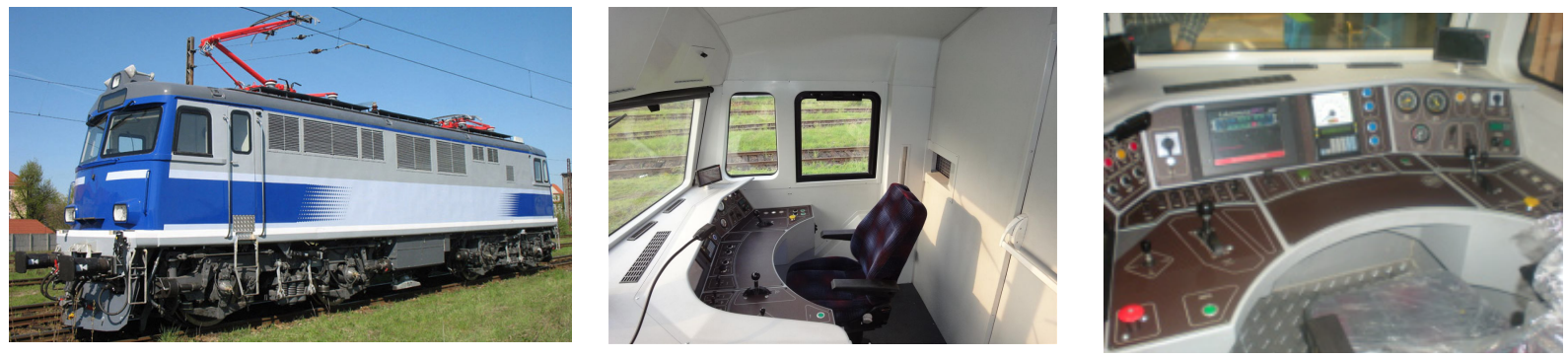

Rys. 25. Widok lokomotywy 303E (EU-07) oraz kabiny po modernizacji z nowymi stanowiskami sterowniczymi

\section{PODSUMOWANIE}

Modernizacja wybranych lokomotyw szczególnie, kabin maszynisty oraz nowe stanowiska sterownicze, zdecydowanie poprawiają warunki pracy maszynistów i pomocników w lokomotywach.

Po przeprowadzonej modernizacji kabiny i wyposażeniu jej w nowoczesne pulpity, warunki pracy personelu obsługującego lokomotywy ulegają znacznej poprawie. 

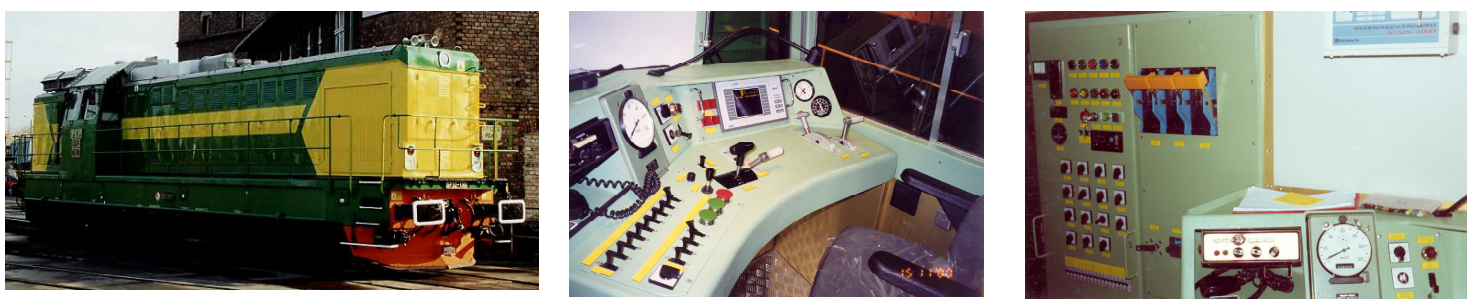

Rys. 26. Widok lokomotywy SP32 oraz kabiny po modernizacji z nowymi stanowiskami sterowniczymi

Podwyższony został komfort pracy dzięki klimatyzacji i wentylacji kabiny, poprawie warunków oświetlenia. Dzięki izolacjom z zastosowanych, nowoczesnych materiałów w wyłożeniach ścian bocznych, suficie oraz nowej konstrukcji i izolacji podłogi, uzyskano znaczne obniżenie poziomu hałasu w kabinie oraz dobrą izolację termiczną.

Dzięki nowej konstrukcji pulpitów możliwe stało się takie ukształtowanie stanowiska (z uwzględnienie warunków przestrzennych w kabinie), że spełnione są wymogi ergonomii układu człowiekfotel-pulpit, widoczności sygnałów na szlaku kolejowym, zgodnie z aktualnymi wymaganiami i normami.

Rozdzielenie na pulpicie poziomu informacyjnego i wykonawczego oraz ich rozmieszczenie w strefach optymalnego zasięgu i widoczności, znacznie poprawiło warunki interakcji człowiekmaszyna, co przyczynia się do poprawy bezpieczeństwa na kolei.

Dodatkowo wyposażenie kabiny w urządzenia socjalne, (lodówkę, umywalkę, urządzenie do podgrzewania posiłków (kuchenkę lub mikrofalówkę), schowki szafki ubraniowe) poprawiło komfort pracy maszynisty i pomocnika.

\section{LITERATURA}

1. Krawczyk J., Guzikowski D., Mockiewicz K.: Opracowanie wytycznych dla kabin maszynisty lokomotywy o prędkości $200 \mathrm{~km} / \mathrm{h} w$ zakresie ergonomii kabiny i fotela maszynisty $w$ powiqzaniu $z$ wymaganiami funkcjonalnymi. Opracowanie OR-7561. OBRPS-Poznań 1991.

2. Krawczyk J., Guzikowski D.: Wytyczne do konstrukcji kabiny maszynisty spetniajacej najnowsze wymagania ergonomiczne. Opracowanie OR-7803. OBRPS-Poznań 1994.

3. Marciniak Z., Krawczyk J. Kabiny sterownicze nowoczesnych lokomotyw, ergonomia, bezpieczeństwo $i$ warunki pracy obstugi. Materiaty z Konferencji Ergonomia W Środkach Transportu. Warszawa, kwiecień 2000.

4. Interfejsy Maszynista-Pojazd dla EMU/DMU, Lokomotyw i Napędnych wagonów osobowych -Funkcjonalne i systemowe wymagania zwiqzane ze wspótpracujacymi Interfejsami Maszynista-Pojazd. Karta UIC-612 wyd.1 Paryż 2009.

5. Uksztattowanie kabin maszynisty lokomotyw, wagonów silnikowych, zespołów trakcyjnych $i$ wagonów sterowniczych. Karta UIC-651 wyd. 2 Paryż 2000.

6. Dokumentacja Techniczno - Ruchowa lokomotywy spalinowej typu 303Da serii ST46 - Opis techniczny. Opracowanie 303Da 0159-1, IPS "TABOR" Poznań, 06.2011.

7. Marciniak Z., Michalak P.; Nowe oraz zmodernizowane uktady i zespoly w modernizowanej lokomotywie spalinowej typu 303D serii SU46, Pojazdy Szynowe 2012, nr 1.

8. Jacek Krawczyk: Modernizacja kabin sterowniczych pojazdów szynowych pod katem wspótczesnych wymaga ergonomii, Politechnika Warszawska. Prace Naukowe. Transport - zeszyt 98, Środki $i$ Infrastruktura Transportu.

9. Krawczyk J. Baza Danych modeli $3 D$ do wykorzystania $w$ dokumentacji konstrukcyjnej modułowych projektów przyszlych lokomotyw elektrycznych i spalinowych. Opracowanie OR-10205. IPS Poznań 2012. 